\title{
Spontaneous Intracranial Hypotension and Central Diabetes Insipidus Coexistence: Neuroradiological View
}

\author{
Spontan Intrakraniyal Hipotansiyon ve Santral Diabetes Insipidus Birlikteliğine \\ Nöroradyolojik Bakış
}

๑1 Esra Demir, (1) Şadiye Gümüşyayla

Ankara Yildirim Beyazit University Faculty of Medicine, Department of Neurology, Ankara, Turkey

Keywords: Headache, diabetes insipidus, spinal anesthesia, spontaneous intracranial hypotension

Anahtar Kelimeler: Baş ağrısı, diyabetes insipidus, spinal anestezi, spontan intrakraniyal hipotansiyon

\section{Dear editor,}

A 37-year-old female patient was admitted to the emergency department with complaints of a headache starting from the neck that increased while standing up, imbalance, nausea, and vomiting. The patient had a history of diabetes insipidus (DI) that developed after a pituitary adenoma surgery 10 years ago and a history of Cesarean section using combined spinal anesthesia 5 days before she was admitted to our clinic. Her neurological examination revealed severe positionally induced bi-frontal cephalgia and horizontal nystagmus. Cranial Magnetic Resonance Imaging (MRI) revealed a subdural hemorrhage extending from the frontal area to the occipital area, lateral ventricle diminution, diffused dural thickening, pontomesencephalic angle narrowing, and dural venous sinuses dilatation (Figure 1). Oral and intravenous analgesic treatment was first administered to the patient, but an adequate clinical response was not obtained due to her DI history, inability to balance urine output, and her hypovolemic state. Thus, oral and subcutaneous desmopressin treatment was administered to the patient due to continuous complaints. The patient had a spinal anesthesia history and MRI findings supported spontaneous intracranial hypotension (SIH), thus cerebrospinal fluid (CSF) was assumed to be leaking. CSF flow MRI and cisternography were performed, which detected a CSF leakage at the 4th-5th lumbar vertebral level (Figure 2). Epidural blood patch (EBP) treatment was given to the patient. The patient's complaints decreased after the EBP treatment and she was discharged after the treatment was completed. In the follow-up cranial MRI of the patient performed one month later, it was observed that the findings related to $\mathrm{SIH}$ were almost completely resolved and that the subdural hematoma was resorbed.

Intracranial hypotension is a disorder that is characterized by postural headache resulting from CSF leakage and low CSF pressure due to a rupture in the arachnoid membrane and/or in the nerve roots exiting from the spine. It spontaneously occurs due to traumatic acquired causes such as lumbar puncture, head and spinal cord traumas, craniotomy, excessive CSF drainage due to shunts, or it occurs due to various metabolic causes such as hyponatremia, hypovolemia, dehydration, and hypernatremia $(1,2)$. Typical MRI findings are dural thickening and contrast enhancement, subdural fluid accumulation (usually hygroma, rarely hematoma), drooping brain, optic chiasm flattening, dural venous sinuses enlargement, increased pituitary height, reduced ventricles, and increased brainstem anteroposterior diameter. Computed tomography, myelography, CSF flow MRI, and radionuclide cisternography were performed as the first step in SIH to detect CSF leakage in patients that are symptomatic and unresponsive to treatment (3). In such patients, EBP is one of the most commonly used invasive treatment methods today $(3,4)$.

DI is a congenital or acquired disease in the spectrum diseases accompanied by polyuria and polydipsia. Pituitary surgeries are frequently among the acquired central causes of this disease, which develop due to central and nephrogenic causes (5). The patient,

Address for Correspondence/Yazışma Adresi: Esra Demir Asst. MD, Ankara Yildirim Beyazit University Faculty of Medicine, Department of Neurology, Ankara, Turkey

Phone: +90 3125526000 E-mail: md.esrademir@gmail.com ORCID: orcid.org/0000-0002-1752-9619 Received/Geliş Tarihi: 30.04.2020 Accepted/Kabul Tarihi: 17.05 .2021

${ }^{\circledR}$ Telif Hakkı 2021 Türk Nöroloji Derneği

Türk Nöroloji Dergisi, Galenos Yayınevi tarafından basılmıştır. 


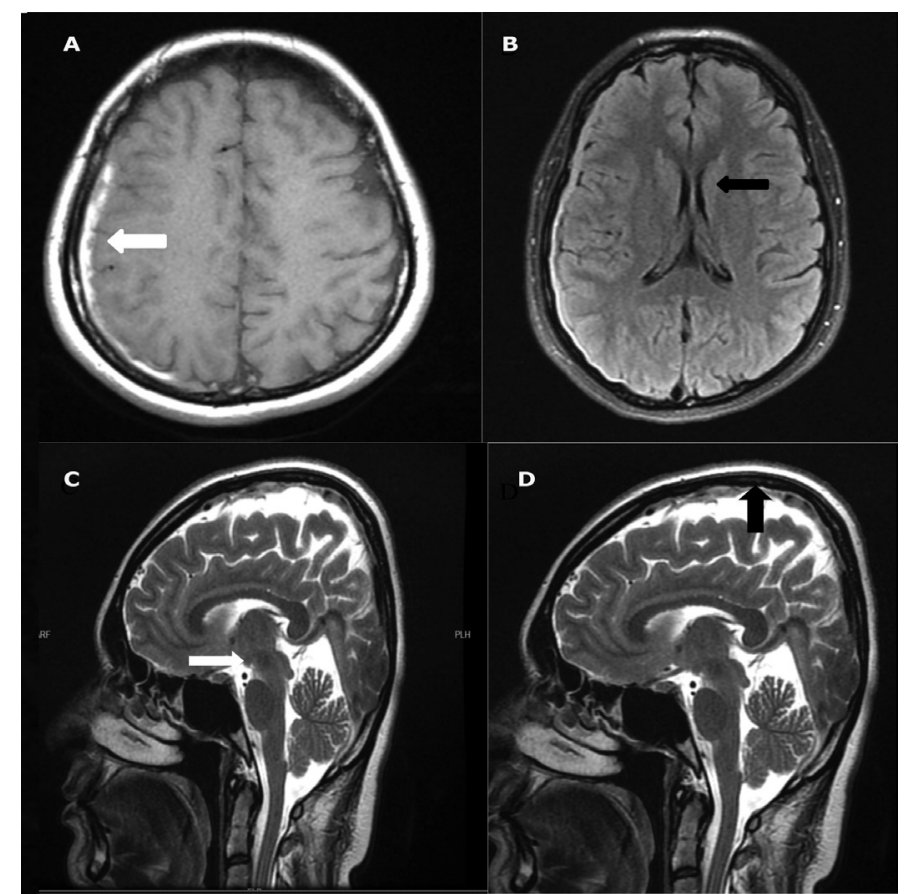

Figure 1. Cranial magnetic resonance imaging (MRI) axial images. (A) Subdural hemorrhage and diffuse dural thickening (white arrow) extending from the frontal area to the occipital area in T1W images. (B) Lateral ventricle diminution (black arrow) in T2W images. Cranial MRI sagittal images. (C) Pontomesencephalic angle narrowing in T2W images (white arrow). (D) Dural venous sinuses dilatation in T2W images (black arrow)

who was receiving oral desmopressin therapy due to iatrogenic DI, was admitted to our clinic after her complaints became continuous. The patient's complaints were evaluated as significant in terms of intracranial hypotension due to a similar pain pattern without analgesic response and due to a recent spinal anesthesia history. In patients whose urine output was not controlled with oral desmopressin during the follow-ups, subcutaneous desmopressin treatment was started, but a partial treatment response was achieved. The hypovolemic state caused by DI in our patient aggravated the SIH findings.

In conclusion, intracranial hypotension seen after spinal anesthesia is many times a clinical diagnosis of exclusion, and patients with comorbidities such as DI should be evaluated together with imaging methods in terms of differential diagnosis. We wanted to draw attention to this condition, which has an effective treatment today and can be fatal if it is not treated.

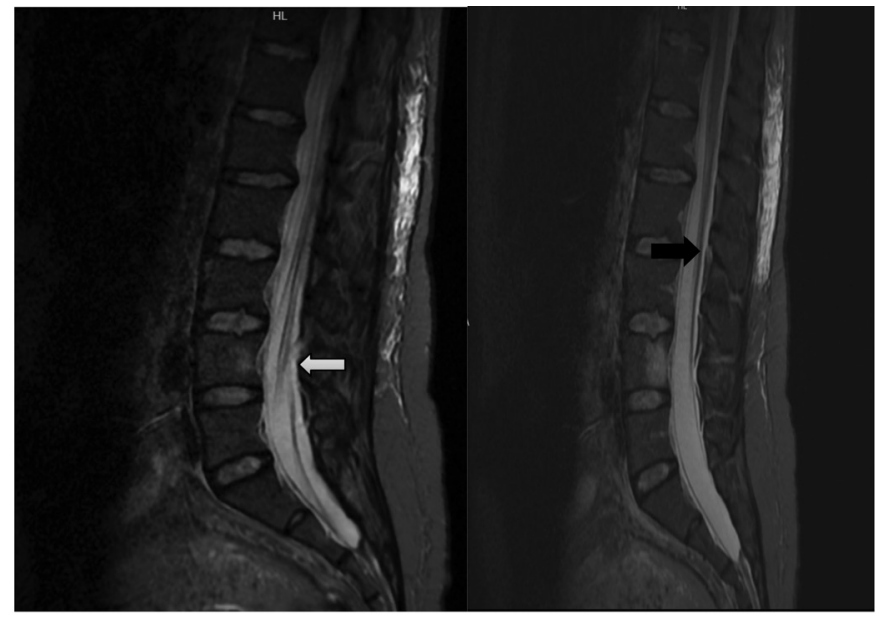

Figure 2. Spinal magnetic resonance imaging, sagittal T2W images show cerebrospinal fluid leakage (white arrow) in the lumbar $4^{\text {th }}-5^{\text {th }}$ region, fluid collection in the extradural area, prominent venous structures, and hyperintensity (black arrow)

\section{Ethics}

Informed Consent: Patient consent was obtained. Peer-review: Externally peer-reviewed.

\section{Authorship Contributions}

Surgical and Medical Practices: E.D., Ş.G., Concept: E.D., Ş.G., Design: E.D., Ş.G., Data Collection or Processing: E.D., Ş.G., Analysis or Interpretation: E.D., Ş.G., Literature Search: E.D., Ş.G., Writing: E.D., Ş.G.

Conflict of Interest: No conflict of interest was declared by the authors.

Financial Disclosure: The authors declared that this study received no financial support.

\section{References}

1. Wang SC, Lirng JF, Hseu SS, Chan KH. Spontaneous intracranial hypotension treated by epidural blood patches. Acta Anaesthesiol Taiwan 2008;46:129-133.

2. Sabancı PA, Baykan B, Kırış T. Sinir Sistemi Hastalıkları/Kafa içi basıncı değişiklikleri. In: Öge E, Baykan B (eds). Nöroloji. İkinci Baskı. İstanbul: Güneş Tip Kitabevi, 2015:222-225.

3. Spears RC. Low pressure/spinal fluid leak headache. Curr Pain Headache Rep 2014;18:425.

4. Schievink WI. Spontaneous spinal cerebrospinal fluid leaks and intracranial hypotension. JAMA 2006;295:2286-2296.

5. Oiso Y, Robertson GL, Noggaard JP, Juul KV. Clinical review: treatment of neurohypophyseal diabetes insipidus. J Clin Endocrinol Metab 2013;98:3958-3967. 